\title{
Gambaran Histopatologik Aorta Tikus yang Diberikan Durian (Durio zibethinus Murr.) Setelah Pemberian Lemak Babi
}

\author{
${ }^{1}$ Jessica P. Limpo \\ ${ }^{2}$ Poppy M. Lintong \\ ${ }^{2}$ Lily Loho
}
${ }^{1}$ Program Studi Pendidikan Dokter Fakultas Kedokteran Universitas Sam Ratulangi Manado ${ }^{2}$ Bagian Patologi Anatomi Fakultas Kedokteran Universitas Sam Ratulangi Manado Email: jessica.limpo@yahoo.com

\begin{abstract}
Hyperlipidemia is a major trigger factor of atherosclerosis. Durian (Durio zibethinus Murr.) has a complex nutrient content such as high energy that can cause obesity resulting in hyperlipidemia. Recently several studies suggest that durian consists of vitamin C, vitamin E, carotenoids, and flavonoid as antioxidants that can inhibit the atherosclerosis process. This study was aimed to obtain the effects of durian administration on histopathologic features of Wistar rat aorta induced by lard. This was an experimental laboratory study using 26 male Wistar rats divided into four groups, as follows: group A (5 rats) without treatment; group B (7 rats), induced with $2 \mathrm{ml}$ of lard twice a day for 28 days; groups C (7 rats), induced with lard for 28 days and then was continued with no treatment for 14 days; group D ( 7 rats), induced with lard for 28 days and was continued with the administration of durian 3,6g/day for 14 days. The results showed that there was a decrease in the number of foam cells in the group that was administered with durian compared to the groups without durian administration. Conclusion: The histopathological features of Wistar rats administered with durian (Durio zibethinus Murr.) after induced with lard showed a smaller number of foam cells compared to the groups without durian administration.
\end{abstract}

Keywords: lard, atherosclerosis, foam cell, durian

\begin{abstract}
Abstrak: Hiperlipidemia merupakan faktor pemicu utama terjadinya aterosklerosis. Durian (Durio zibethinus Murr.) memiliki kandungan gizi yang kompleks seperti energi tinggi yang dapat menyebabkan kegemukan dan berimbas pada keadaan hiperlipidemia. Beberapa sumber menyatakan bahwa durian mengandung beberapa jenis antioksidan yang dapat menghambat terjadinya proses aterosklerosis. Penelitian ini bertujuan untuk mendapatkan efek pemberian durian terhadap gambaran histopatologik aorta tikus Wistar yang diberikan lemak babi. Jenis penelitian ialah eksperimental laboratorik, menggunakan 26 ekor tikus Wistar yang dibagi menjadi empat kelompok yaitu kelompok A (5 ekor tikus) tanpa perlakuan; kelompok B (7 ekor tikus) diberikan lemak babi dua kali sehari sebanyak $2 \mathrm{ml} / \mathrm{kali}$ selama 28 hari; kelompok C (7 ekor tikus) diberikan lemak babi selama 28 hari dilanjutkan tanpa perlakuan selama 14 hari; kelompok D (7 ekor tikus) diberikan lemak babi selama 28 hari dan dilanjutkan dengan pemberian durian sebanyak 3,6g/hari selama 14 hari. Hasil penelitian ini mendapatkan pengurangan jumlah sel busa pada kelompok yang diberikan durian dibandingkan kelompok tanpa pemberian durian. Simpulan: Tikus Wistar yang diberikan durian (Durio zibethinus Murr.) setelah pemberian lemak babi menunjukkan gambaran histopatologik aorta dengan jumlah sel busa yang lebih sedikit dibandingkan dengan yang tanpa pemberian durian.
\end{abstract}

Kata kunci: lemak babi, aterosklerosis, sel busa, durian 
Tingginya angka kejadian penyakit jantung di Provinsi Sulawesi Utara tidak lepas dari kebiasaan masyarakatnya yang gemar mengonsumsi makanan tinggi lemak seperti produk olahan babi. ${ }^{1}$ Kandungan lemak pada babi mencapai $100 \mathrm{~g} / 100 \mathrm{~g}$ lemak dan dapat menyebabkan terjadinya hiperlipidemia yang merupakan faktor utama pemicu terjadinya penyumbatan pembuluh darah yang dikenal sebagai aterosklerosis. ${ }^{2,3}$

Pada mulanya, aterosklerosis terbentuk karena adanya cedera endotel yang menyebabkan terjadinya peningkatan permeabilitas, serta perlekatan leukosit dan trombosit. Sel yang cedera akan mengalami inflamasi dan memroduksi sitokin-sitokin inflamasi seperti tumor necrosis factoralpha (TGF- $\alpha$ ), interferon-gamma (IFN- $\gamma$ ), interleukin-1 (IL-1), dan oksigen toksik. Melalui vascular adhesion molecule-1 (VCAM-1) akan terjadi migrasi monosit ke dalam jaringan menjadi makrofag yang menghasilkan oksigen toksik yang akan berikatan dengan low density lipoprotein (LDL) membentuk LDL teroksidasi. Selain itu, makrofag juga berperan dalam memfagositosis benda asing dalam hal ini LDL teroksidasi yang kemudian membentuk sel busa.,

Keadaan hiperlipidemia menyebabkan banyaknya jumlah LDL yang beredar dalam darah sehingga semakin banyak pula sel busa yang terbentuk. Pada keadaan ini, akan diproduksi faktor pertumbuhan seperti platelet-derived growth factor (PDGF), fibroblast growth factor, dan transforming growth factor-alpha (TGF- $\alpha$ ) yang akan menstimulasi proliferasi otot polos. Proliferasi otot polos dan penimbunan matriks ekstrasel akan mengakibatkan lesi paling dini yaitu lapisan lemak fatty streak yang selanjutnya berubah menjadi bercak ateroma. Perubahan fatty streak menjadi bercak ateroma membutuhkan waktu bertahun-tahun tergantung pada faktor pemicunya. Beberapa buah dapat menjadi pemicu ataupun penghambat terjadinya proses aterosklerosis, salah satunya yaitu durian. ${ }^{3-6}$

Durian (Durio zibethinus Murr.) merupakan tanaman yang tumbuh subur di daerah tropis, salah satunya di Indonesia. ${ }^{7}$ Daging buah durian dikenal kaya akan karbohidrat, protein, dan lemak sehingga bila dikonsumsi dalam jumlah berlebih dapat menyebabkan kegemukan yang berujung pada keadaan hiperlipidemia. Selain itu, durian memiliki kandungan gizi yang sangat kompleks, salah satunya kandungan antioksidan yang tinggi seperti vitamin $\mathrm{C}$, vitamin $\mathrm{E}$, karotenoid, dan flavonoid yang dapat menghambat terjadinya proses aterosklerosis. ${ }^{7-12}$ Tujuan penelitian ini untuk mengetahui efek pemberian durian terhadap gambaran histopatologik aorta dari tikus yang diberikan lemak babi.

\section{METODE PENELITIAN}

Jenis penelitian ini ialah eksperimental laboratorium yang dilakukan di Laboratorium Patologi Anatomi Fakultas Kedokteran Universitas Sam Ratulangi Manado pada bulan September sampai dengan bulan Desember 2017. Subyek penelitian ialah 26 ekor tikus Wistar jantan berusia 2-3 bulan dengan berat rata-rata $200 \mathrm{~g}$.

Pada penelitian ini digunakan lemak babi yang diambil dengan teknik $d r y$ rendering dan durian jenis Monthong yang diolah menjadi jus dengan cara diblender. ${ }^{5,13}$

Tikus Wistar dipelihara dalam kandang yang telah diberikan dedak dan diberikan makan dengan pelet AD2 selama 7 hari agar tikus dapat beradaptasi. ${ }^{14}$ Untuk pemberian lemak babi, tikus diberikan lemak babi dua kali sehari sebanyak $2 \mathrm{ml} / \mathrm{kali}$ dengan menggunakan sonde. Penentuan pemberian dosis ini berdasarkan pada penelitian sebelumnya yang menyatakan bahwa dengan dosis tersebut telah dapat memicu lesi awal aterosklerosis. ${ }^{1,15}$ Dosis durian yang diberikan didasarkan pada dosis anjuran dalam mengonsumsi durian yaitu 3,6 g/hari (dosis yang telah dikonversi). ${ }^{8}$

Subyek penelitian sebanyak 26 ekor tikus Wistar jantan dikelompokkan ke dalam empat kelompok yaitu: 
1. Kelompok A (kontrol negatif) terdiri dari 5 ekor tikus, hanya diberikan makan pelet $\mathrm{AD} 2$ dan minum air selama 28 hari dan kemudian diterminasi pada hari ke 29.

2. Kelompok B (kontrol positif) terdiri dari 7 ekor tikus, diberikan lemak babi dua kali sehari sebanyak $2 \mathrm{ml} / \mathrm{kali}$ dan makan pelet AD2 selama 28 hari dan diterminasi pada hari ke-29.

3. Kelompok C (perlakuan I) terdiri dari 7 ekor tikus, diberikan lemak babi dua kali sehari sebanyak $2 \mathrm{ml} / \mathrm{kali}$ bersamaan dengan makan pelet AD2 selama 28 hari kemudian pemberian lemak babi dihentikan dan pemberian makan pelet AD2 dilanjutkan selama 14 hari.

4. Kelompok D (perlakuan II) terdiri dari 7 ekor tikus, diberikan perlakuan yang sama dengan kelompok $\mathrm{C}$ namun dengan intervensi durian setelah pemberian lemak babi sebanyak $3,6 \mathrm{~g} /$ hari selama 14 hari.

\section{HASIL PENELITIAN}

Pada akhir penelitian, tersisa sebanyak

17 ekor tikus dengan pembagian yaitu kelompokA sebanyak 4 ekor, kelompok B sebanyak 5 ekor, kelompok C dan D masing-masing sebanyak 4 ekor. Hal ini dikarenakan beberapa ekor tikus mati akibat mengalami aspirasi pada awal pemberian lemak babi. Pada penelitian ini, beberapa ekor tikus mendapatkan perlakuan dengan waktu yang tidak sesuai dengan seharusnya. Waktu pemberian perlakuan yang bervariasi namun tetap terdapat pembanding di masing-masing kelompok. Perbedaan waktu ini disebabkan banyaknya tikus yang mengalami aspirasi pada awal perlakuan sehingga perlakuan diberikan pada tikus yang baru dengan waktu yang lebih singkat agar sesuai dengan waktu penelitian yang telah ditentukan.

Gambaran makroskopik aorta tikus wistar pada semua kelompok (Kelompok A - D) tidak berbeda jauh, walaupun waktu perlakuan yang diberikan bervariasi. Aorta tikus pada kelompok A (Kontrol negatif) tampak berwarna merah kecoklatan dengan konsistensi kenyal dan permukaan yang halus. Gambaran makroskopik aorta ini juga ditemukan pada semua kelompok perlakuan (Kelompok B - D).

\section{Gambaran mikroskopik aorta tikus Wistar \\ Kelompok A}

Kelompok ini terdiri dari 4 ekor tikus Wistar yang hanya diberikan pelet AD2 tanpa perlakuan tambahan selama 28 hari. Gambaran histopatologik aorta tikus Wistar pada kelompok ini tampak normal. Pada pemeriksaan di bawah mikroskop dapat dilihat adanya tunika intima, tunika media, dan tunika adventisia dalam batas normal. Pada aorta tikus kelompok ini tidak ditemukan adanya gambaran sel busa baik pada tunika intima maupun tunika medianya (Gambar 1A).

\section{Kelompok B}

Pada kelompok B terdapat 5 ekor tikus Wistar yang diberikan lemak babi dua kali sehari sebanyak $2 \mathrm{ml} / \mathrm{kali}$. Tikus kelompok ini mendapatkan perlakuan dengan waktu yang bervariasi yaitu 14 hari, 18 hari, 21 hari, dan 28 hari.

Waktu perlakuan yang berbeda ini disebabkan karena terjadinya aspirasi pada saat pemberian lemak babi yang berujung pada kematian tikus. Tikus yang mati tersebut langsung dibedah dan diambil jantung beserta aorta tikus untuk diperiksa.

Dari hasil pemeriksaan, ditemukan adanya gambaran sel busa pada tunika intima dan tunika media pada aorta semua tikus yang makin bertambah banyak dengan pertambahan waktu perlakuan (Gambar 1 B-D).

\section{Kelompok C}

Tikus Wistar pada kelompok C diberikan pelet $\mathrm{AD} 2$ bersamaan dengan lemak babi sebanyak $4 \mathrm{ml} / \mathrm{hari}$ dalam dua kali pemberian. Pada akhir perlakuan, tersisa sebanyak 4 ekor tikus Wistar jantan yaitu 2 ekor tikus diberikan pelet AD2 bersamaan dengan lemak babi selama 28 hari dan dilanjutkan dengan pemberian pelet saja selama 14 hari sedangkan 2 ekor tikus lainnya diberikan pelet bersamaan 
dengan lemak babi selama 21 hari dan dilanjutkan dengan pelet saja selama 7 hari. Hal ini bertujuan untuk menjadi pembanding antara tikus Wistar pada kelompok B dengan tikus pada kelompok C. Gambaran histopatologik pada kelompok ini mendapatkan adanya sel busa dengan jumlah yang tidak jauh berbeda dengan tikus Wistar pada kelompok B (Gambar 1E fan F).

\section{Kelompok D}

Pada akhir perlakuan, tikus Wistar

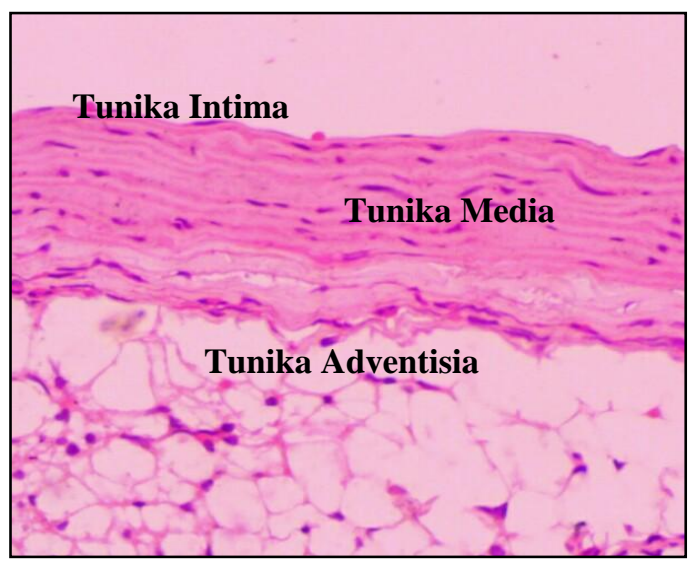

Gambar 1A. Gambaran histopatologik aorta kelompok A tampak normal dengan tunika intima yang utuh; tidak ditemukan adanya sel busa. (Pembesaran 400x)

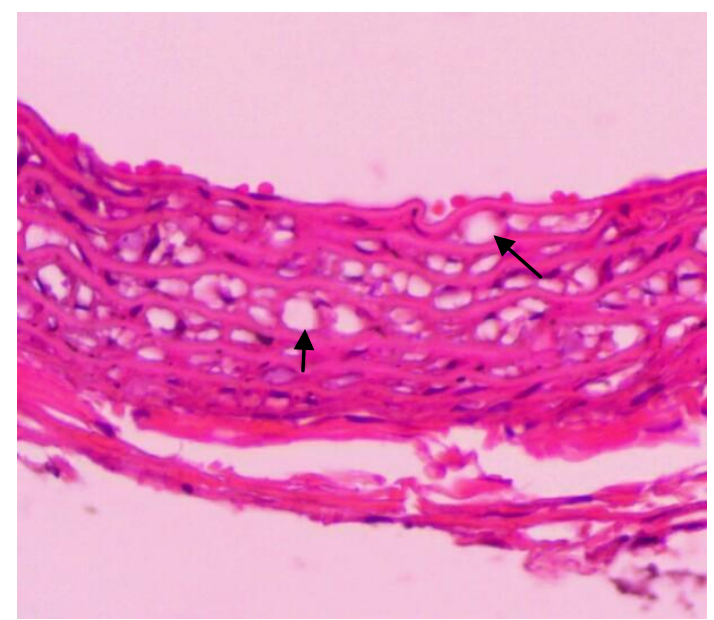

Gambar 1C. Gambaran histopatologik kelompok B yang diberikan lemak babi selama 21 hari. Tampak sel-sel busa yang lebih banyak dalam tunika intima dan tunika media aorta. (Pembesaran 400x) pada kelompok D tersisa empat ekor tikus yang diberikan pelet AD2 bersamaan dengan lemak babi dengan waktu pemberian yang sama seperti kelompok $\mathrm{C}$ dan dilanjutkan dengan pemberian durian sebanyak 3,6 g/hari atau setara dengan \pm 2 $\mathrm{ml} /$ hari. Pada gambaran histopatologik dapat dilihat terdapatnya sel busa dalam jumlah yang cukup banyak pada beberapa bagian aorta dan pada bagian lain tidak ditemukan sel busa (Gambar $1 \mathrm{G}$ dan $\mathrm{H}$ ).

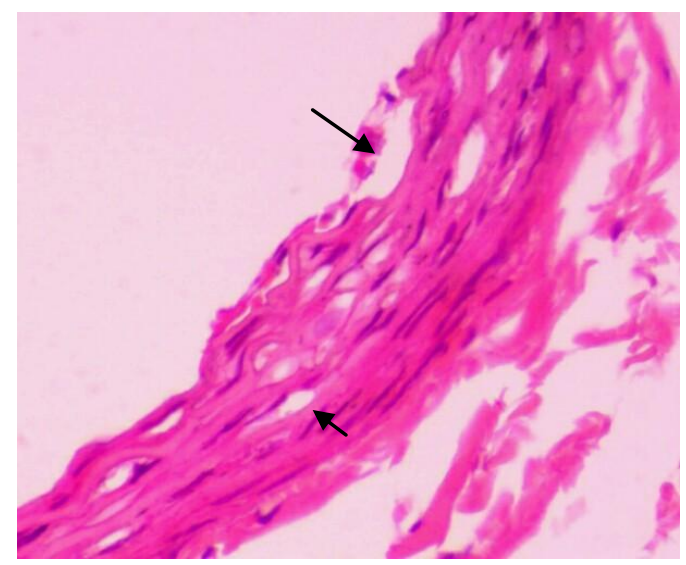

Gambar 1B. Gambaran histopatologik kelompok B yang diberikan lemak babi selama 14 hari. Tampak gambaran sel busa dalam tunika intima dan tunika media aorta tikus (panah hitam). (Pembesaran 400x)

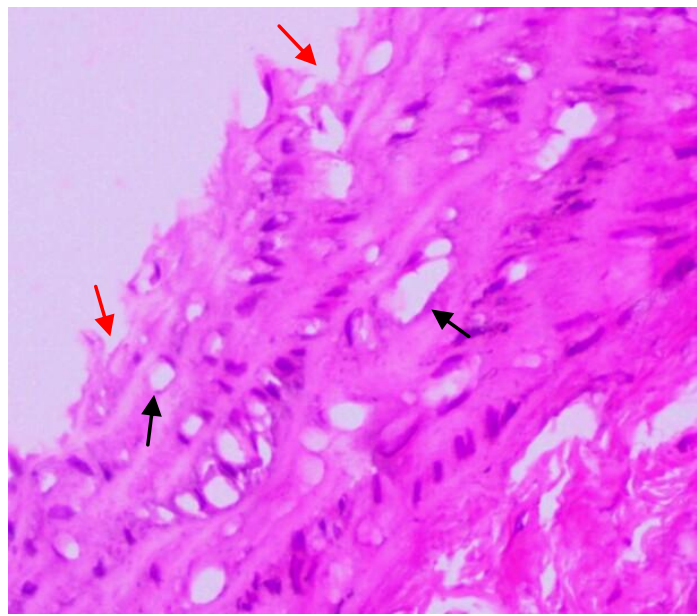

Gambar 1D. Gambaran histopatologik kelompok B yang diberikan lemak babi selama 28 hari. Tampak sel-sel busa dalam tunika intima dan tunika media aorta tikus (panah hitam), dan disertai cedera endotel pada tunika intima (panah merah). (Pembesaran 400x) 


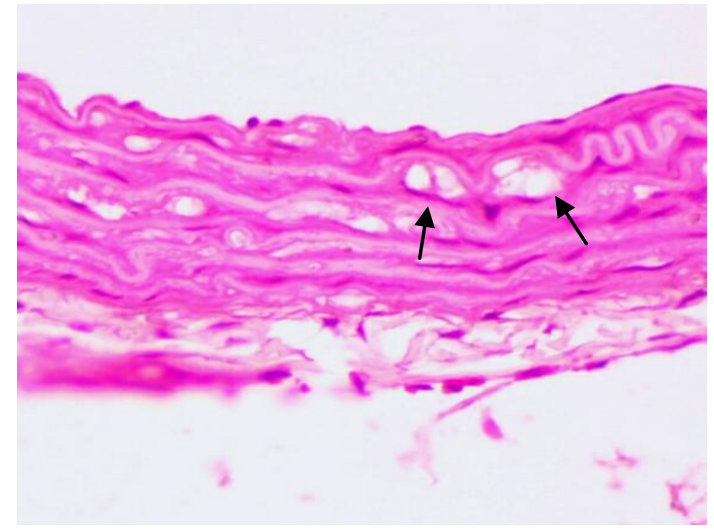

Gambar 1E. Gambaran histopatologik kelompok $\mathrm{C}$ yang diberikan lemak babi selama 28 hari dilanjutkan pemberian pelet AD2 selama 14 hari. Tampak sel busa dalam tunika intima dan tunika media aorta tikus dibandingkan kelompok B (panah hitam). (Pembesaran 400x)

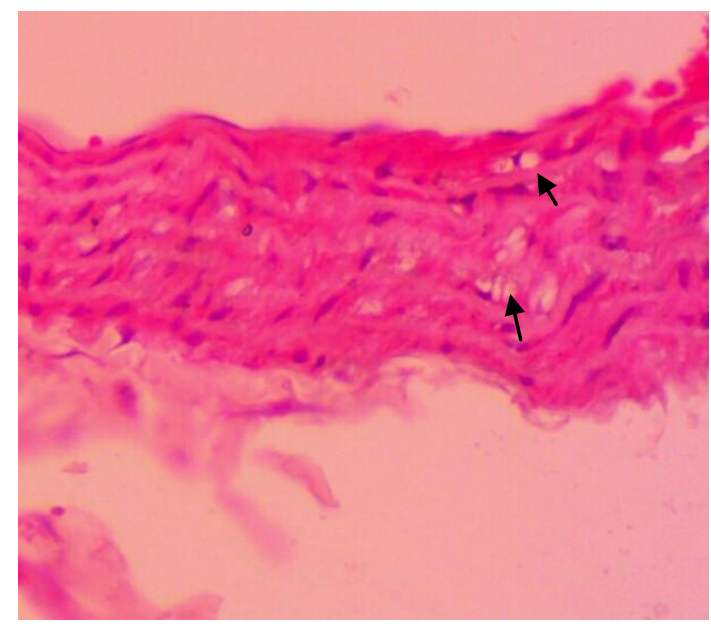

Gambar 1G. Gambaran histopatologik kelompok D yang diberikan lemak babi selama 28 hari dilanjutkan pemberian durian selama 14 hari. Ditemukan adanya sel busa pada sebagian daerah dalam jumlah sedikit. Pembesaran 400x

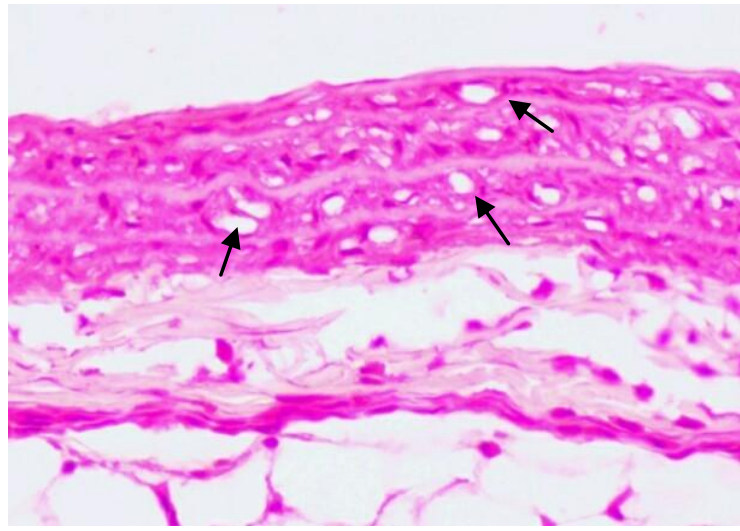

Gambar 1F. Gambaran histopatologik kelompok C yang diberikan lemak babi selama 21 hari dilanjutkan pemberian pelet AD2 selama 7 hari. Tampak jumlah sel busa dalam tunika intima dan tunika media aorta tikus dibandingkan kelompok B (panah hitam). (Pembesaran 400x)

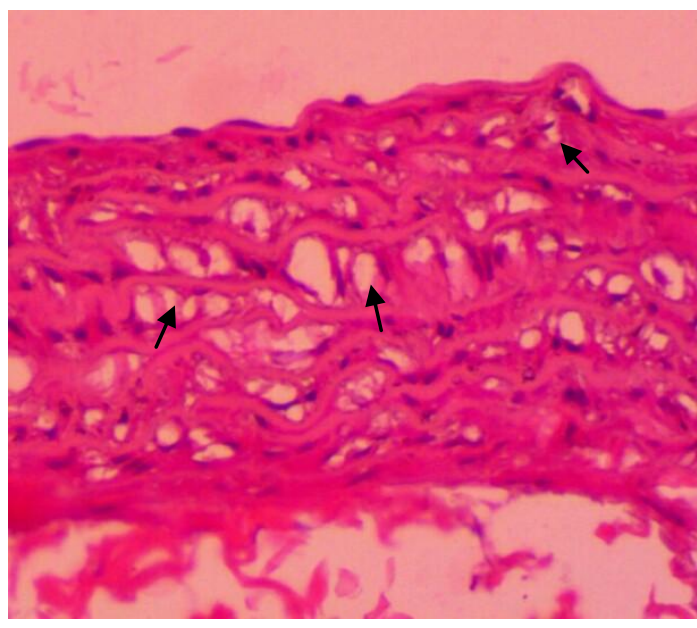

Gambar 1H. Gambaran histopatologik kelompok D yang diberikan lemak babi selama 28 hari dilanjutkan durian selama 14 hari pada perbesaran 40 kali. Tampak sel busa dalam tunika intima dan tunika media aorta tikus (panah hitam). Pembesaran 400x

Gambar 1. Gambaran histopatologik aorta tikus Wistar dari keempat kelompok penelitian. 1A, Kelompok A; 1B-D, Kelompok B; 1E-F, Kelompok C; 1G-H, Kelompok D.

\section{BAHASAN}

Durian memiliki kandungan gizi yang kompleks dengan banyak manfaat seperti sebagai sumber energi, mencegah depresi, mencegah anemia, melancarkan pencernaan, dan menjaga kesehatan tulang., ${ }^{5,8,9}$ Beberapa penelitian tentang kadar antioksidan dalam durian menyatakan bahwa durian memiliki kandungan antioksidan yang beragam dengan jumlah yang cukup tinggi. Dalam durian terkandung vitamin $\mathrm{C}$, vitamin E, karotenoid, dan flavonoid yang dapat menghambat terjadinya proses aterosklerosis. ${ }^{7-12}$ Berdasarkan penelitian sebeumnya, pemberian lemak babi untuk beberapa waktu tertentu dapat menyebabkan terbentuknya sel busa dalam tunika intima dan tunika media aorta tikus. ${ }^{1,15}$ 
Penelitian ini bertujuan untuk melihat efek pemberian durian terhadap gambaran histopatologik aorta tikus setelah pemberian lemak babi.

Tikus pada kelompok kontrol negatif (kelompok A) memiliki gambaran mikroskopik aorta dalam batas normal (Gambar 1A). Lapisan pembuluh darah masih utuh seperti gambaran normal dari histologik aorta. Juga tidak ditemukan adanya sel busa dalam lapisan pembuluh darah tersebut.

Tikus yang diberikan lemak babi dua kali sehari sebanyak $2 \mathrm{ml} / \mathrm{kali}$ (kelompok B) menunjukkan gambaran mikroskopik adanya sel busa dalam tunika intima dan tunika media. Rentang waktu pemberian lemak babi yang makin lama memperlihatkan makin banyak sel busa yang terbentuk (Gambar 1 B-D). Hal ini dikarenakan lemak babi memiliki kandungan lemak total yang tinggi yakni sebesar 100 g/100 g lemak. ${ }^{2}$ Kandungan lemak yang tinggi ini dapat menyebabkan terjadinya cedera endotel yang merupakan mekanisme awal terjadinya aterosklerosis. Ketika terjadi cedera endotel maka akan terjadi migrasi monosit dari peredaran darah ke dalam tunika intima dan berdiferensiasi menjadi makrofag yang akan menghasilkan radikal bebas berinteraksi dengan LDL membentuk LDL teroksidasi. Selain menghasilkan radikal bebas, makrofag memainkan perannya dalam memfagositosis benda asing dalam hal ini LDL teroksidasi. Makrofag bersama LDL teroksidasi ini akan membentuk sel busa dalam tunika intima pembuluh darah. Pada manusia, sel busa hanya ditemukan dalam tunika intima sedangkan pada tikus sel busa dapat ditemukan hingga tunika media pembuluh darah. Keadaan hiperlipidemia secara terus-menerus dapat menyebabkan perkembangan lebih lanjut dari sel busa menjadi bercak ateroma sehingga dapat menyumbat pembuluh darah. ${ }^{3}$

Pada tikus kelompok $\mathrm{C}$ yang diberikan pelet AD2 selama 14 hari dan 7 hari setelah pemberian lemak babi menunjukkan gambaran mikroskopik yang pada dasarnya sama seperti gambaran mikroskopik pada tikus kelompok B. Namun yang membeda- kannya yaitu pada tikus kelompok C memperlihatkan jumlah sel busa dalam tunika intima dan tunika media yang lebih sedikit (Gambar 1 E dan F). Hal ini dikarenakan adanya pengurangan asupan lemak sehingga berdampak pada penurunan kadar kolesterol secara bertahap. ${ }^{16}$

Tikus pada kelompok D yang diberikan intervensi dengan durian selama 14 hari dan 7 hari setelah pemberian lemak babi menunjukkan adanya sel busa pada gambaran histopatologik aorta tikus dengan jumlah yang bervariasi. Hal ini mungkin disebabkan karena vitamin $\mathrm{C}$ dalam durian merupakan antioksidan larut dalam air yang berperan dalam menghambat proses peroksidasi lipid dengan mendonorkan satu elektronnya pada radikal lipid, meningkatkan laju ekskresi kolesterol dalam asam empedu, meningkatkan kadar HDL, menurunkan kemampuan untuk menyerap asam empedu, menyintesis kolagen sehingga terjadi regenerasi jaringan endotel, dan juga dapat menghambat terjadinya adhesi leukosit sebagai tahap dari respon cedera endotel dalam proses aterosklerosis. ${ }^{17,18}$

Selain vitamin C, terdapat pula vitamin E dan karotenoid yang juga berperan sebagai antioksidan. Vitamin E bereaksi dengan radikal bebas peroksil lipid sehingga terjadi pemutusan reaksi peroksidasi lipid dan menghasilkan radikal tokoferol yang bersifat stabil. Selain itu, vitamin E juga berperan dalam menghambat pembentukan kolesterol melalui reaksi dengan oksigen membentuk alfa tokoferilkuinon yang akan menghambat pembentukan skualen 2,3 oksida. ${ }^{17,19}$ Karotenoid berperan dalam melindungi membran sel dan menangkap radikal bebas peroksil lipid sehingga dapat mencegah terjadinya kerusakan dinding sel akibat radikal bebas. ${ }^{17}$ Antioksidan lain yang ditemukan pada durian yaitu flavonoid yang merupakan senyawa fenol yang bekerja dengan cara mendonorkan atom hidrogen-nya sehingga radikal bebas tidak dapat bereaksi dengan LDL dan pada akhirnya terjadi pengurangan sel busa. ${ }^{20}$

Gambaran histopatologik pada kelompok B dan C secara kualitatif terdapat sel- 
sel busa yang tersebar secara difus yang berbeda dibandingkan dengan kelompok D. Pada kelompok D didapatkan sel busa dengan jumlah besar pada sebagian daerah aorta sedangkan pada bagian lainnya ditemukan sel busa dalam jumlah lebih sedikit atau bahkan tidak ditemukan sama sekali. Dapat dikatakan bahwa efek pemberian durian terhadap gambaran histopatologik aorta tikus setelah pemberian lemak babi cukup berperan dalam mengurangi pembentukan sel busa dakam lapisan pembuluh darah.

\section{SIMPULAN}

Berdasarkan hasil penelitian ini dapat disimpulkan bahwa pada tikus Wistar (Rattus norvegicus) yang diberikan durian (Durio zibethinus Murr.) setelah pemberian lemak babi didapatkan sel busa dalam tunika intima dan tunika media aorta dengan jumlah yang bervariasi. Namun secara keseluruhan sel busa lebih sedikit dibandingkan dengan kelompok tanpa pemberian durian.

\section{SARAN}

Perlu dilakukan penelitian lebih lanjut untuk membuktikan efek mengonsumsi durian dapat menghambat proses aterosklerosis pada dosis dan waktu yang berbeda.

Untuk penelitian selanjutnya perlu dilakukan pengukuran kadar kolesterol darah tikus normal tanpa perlakuan, tikus yang diberikan lemak babi, dan tikus yang diberikan intervensi dengan durian.

Untuk penelitian lebih lanjut dapat dilakukan penghitungan jumlah sel busa secara kuantitatif dan analisis statistik mengenai efek mengonsumsi durian dalam menghambat proses aterosklerosis.

Perlu dilakukan penelitian lebih lanjut dengan menggunakan tikus strain tertentu yang telah mengalami proses transgenetik sehingga hasil yang diperoleh lebih akurat.

Perlu dilakukan penelitian lebih lanjut dengan menggunakan ekstraksi daun durian untuk melihat efek kandungan antioksidan daun durian dalam menghambat proses aterosklerosis.

\section{DAFTAR PUSTAKA}

1. Papodi NN, Durry MF, Kairupan CF. Pengaruh ekstrak daun gedi (Abelmoschus manihot L.) terhadap gambaran histopatologi aorta tikus wistar dengan diet aterogenik [Skripsi]. Manado: Fakultas Kedokteran Universitas Sam Ratulangi; 2014.

2. United State Department of Agriculture. National nutrient database for standard reference release 28. May 2016 [cited 2017 August 29]. Available from: https://ndb.nal.usda.gov/ndb/foods/ show $/ 635$ ?fgcd $=\&$ manu $=\&$ lfacet $=\&$ for mat $=\&$ count $=\& \max =50 \&$ offset $=\&$ sort $=$ default $\&$ order $=$ asc $\& q$ lookup $=$ lard $\& d s$ $=\& \mathrm{q}=\& \mathrm{qp}=\& \mathrm{q} a=\& \mathrm{qn}=\& \mathrm{q}=\&$ ing

3. Kumar V, Abbas AK, Aster JC. Buku Ajar Patologi Robbins (9th ed). Nasar IM, Cornain S, editors; Perkins JA, ilustrator. Singapura: Elsevier, 2015; p. 329-36.

4. Lintong PM. Perkembangan konsep patogenesis aterosklerosis. JBM. 2009; 1(1):12-22.

5. Ramadhani R, Sadikin M. The effect of durian (Durio spp.) consumption on the blood high-density lipoprotein level [Skripsi]. Jakarta: Fakultas Kedokteran Universitas Indonesia; 2014.

6. Leontowicz H, Leontowicz $M$, Jesion I, Bielecki W, Poovarodom S, Vearasilp S, et al. Positive effects of durian fruit at different stages of ripening on the hearts and livers of rats fed diets high in cholesterol. Eur J Integrative Med. 2011;3:e169-e181.

7. Saparinto C, Susiana R. Grow your own fruits - Panduan praktis menanam 28 tanaman buah populer di pekarangan (1st ed). Yogyakarta: Lily Publisher, 2017; p. 117-20, 124-25.

8. Balai Penelitian Tanaman Buah Tropika. 1001 manfaat durian untuk kesehatan. 2012. [cited 2017 Aug 1]. Available from: http://balitbu.litbang.pertanian.go.id/ ind/index.php/berita-mainmenu-26/13info-aktual/339-1001-manfaat-durianuntuk-kesehatan.

9. Tirtawinata MR, Santoso PJ, Apriyanti LH. Durian - Pengetahuan Dasar untuk Pecinta Durian (1st ed). Jakarta: Agriflo, 2016; p. 9, 12-5.

10. Amri AAU, Maskoen AM, Hidayat S. Durian consumption effect on plasma 
malondialdehyde level as biomarker of stress oxidative in rats. AMJ. 2016;3(1):22-8.

11. Charoenkiatkul S, Thiyajai $P$, Judprasong K. Nutrients and bioactive compounds in popular and indigenous durian (Durio zibethinus murr.). Food Chemistry. 2015;193: 181-6.

12. Kantor Deputi Menegristek Bidang Pendayagunaan dan Pemasyarakatan Ilmu Pengetahuan dan Teknologi. Durian. 2012; p. 1. [cited 2017 Aug 18]. Available from: http:// syekhfanismd.lecture.ub.ac.id/files/201 2/12/DURIAN.pdf

13. Assifa P. Analisis minyak babi pada krim pelembab wajah yang mengandung minyak zaitun dengan menggunakan spektroskopi fourier transform infrared (FTIR) [Skripsi]. Jakarta: Fakultas Kedokteran dan Ilmu Kesehatan (Program Studi Farmasi) UIN Syarif Hidayatullah; 2013.

14. Widiartini W, Siswati E, Setiyawati A, Rohmah IM, Prasetyo E. Pengembangan usaha produksi tikus putih (Rattus norvegicus) tersertifikas dalam upaya memenuhi kebutuhan hewan laboratorium. PKM-K. 2013. Available from: artikel.dikti.go.id/
index.php/PKMK/article/view/149.

15. Polii LSF, Wongkar D, Wangko S. Gambaran histologik aorta kelinci yang diinduksi dengan lemak babi dan diberi ekstrak beras hitam. eBm. 2016;4(1).

16. Iswari RS, Manalu W. Biokimia dan Fisiologi Lipid. Bandung: Karya Putra Darwati, 2011; p. 87, 88, 100-3, 12431.

17. Nimse SB, Pal D. Free radicals, natural antioxidants, and their reaction mechanisms. RSC Adv. 2015;5: 2798628006.

18. Matondang HF, Nissa C. Pengaruh pemberian sari belimbing wuluh (Averrhoa bilimbi. L) terhadap kadar kolesterol total wanita dewasa. JNH. 2017;5(3):4-17.

19. Andari F. Pengaruh pemberian serbuk biji labu kuning (Cucurbita moschata) terhadap penurunan kolesterol total pada tikus wistar hiperkolesterolemia [Skripsi]. Semarang: Fakultas Kedokteran (Program Studi Ilmu Gizi) Universitas Diponegoro; 2014.

20. Redha A. Flavonoid: Struktur, sifat antioksidan dan perannya dalam sistem biologis. Jurnal Belian. 2010;9(2):196202. 